\title{
RHOC Gene
}

National Cancer Institute

\section{Source}

National Cancer Institute. RHOC Gene. NCI Thesaurus. Code C18358.

This gene plays a role in signal transduction. It is involved in several cellular functions including cytoskeletal remodeling and cell differentiation. 